\title{
Legal Issues Related to the Requisition of Japanese Yōkai in Intellectual Property Law: The Conflict Between Fair Use, Communal Culture, and Private Ownership
}

\author{
Anthony G. A. Shaw \\ BA; LLB (Hons) University of Queensland, Brisbane, Queensland, Australia.
}

\begin{abstract}
Despite having a strong basis in the cultural heritage of Japan, Japanese folklore spirits, also known as yōkai, have often been excluded from being protected as cultural heritage, and are often privately trademarked and used in a multi-billion-dollar entertainment industry. Through these trademarks, rights holders have inconsistent and overlapping privatized entitlement to what is essentially shared cultural heritage, which forms a chasm in Japanese copyright protections. This has negative consequences for the public use and enjoyment of cultural heritage. This essay takes a socio-legal approach and proposes that yōkai being catalogued and protected under the protections granted by the Convention for the Safeguarding of Intangible Cultural Heritage would be a positive step, but is ultimately not a viable solution to this issue, and instead the lack of fair use protections in Japanese copyright law should be expanded to include a defence for the use of cultural heritage forms such as yōkai.
\end{abstract}

Keywords: intellectual property law, cultural heritage law, Japanese law, Yōkai, communal culture

\section{Introduction}

Folklore and cultural heritage is of international significance as many commercialized narratives are based on folk tales that are reimagined for modern audiences. Within Japan, yōkai are of considerable commercial value (Shamoon, 2013, p. 276), and yōkai feature prominently in both Japanese folklore and modern narratives. The term yōkai is broad, encompasses a variety of folkloric forms, and can be translated to mean monsters, demons, and spirits (Shamoon, 2013, p. 276). Due to their recognizable nature as cultural artefacts, yōkai have become popular as corporate mascots, town symbols, merchandising, representations of natural landmarks, and as source material for modern popular culture narratives (Shamoon, 2013, p. 276). Notably, yōkai are of significant importance to the Japanese financial sector and are of large commercial value as they are prominent in production, marketing, and the distribution of goods and services (Kono, 2009, p. 18).

Despite the prevalent usages of $y \overline{o k a i}$, Japanese intellectual property law has notoriously strong moral rights enshrined within the Chosakukeho (Copyright Law of Japan, 1970). These strict moral rights do not permit a distinct defense for fair use, and common fair-use defenses to copyright infringement in other jurisdictions, such

Anthony G. A. Shaw, Diabetes Research Laboratories, School of Clinical Medicine Prince Charles Hospital Northside Clinical Unit, Faculty of Medicine, BA; LLB (Hons) University of Queensland, Brisbane, Queensland, Australia. 
as parody, are not recognizable as a permissible use of copyright protected work without the rights holder's explicit consent (Foster, 2013, pp. 313, 318). ${ }^{1}$ As a result, uses of yōkai and other socio-cultural characters within Japanese cultural heritage are under threat of litigation.

This paper takes a critical legal theory approach that rejects the premise that law exists in a socio-political vacuum (Anderson, 2009, p. 32), and further draws upon theories of cultural studies anthropological thought to critically assess the applicability and viability of intellectual property law to cultural heritage.

\section{Justifications for a Critical Evaluation Intellectual Property Law's Regulation of Cultural Heritage in a Japanese Context}

Global efforts to legally catalogue and recognize cultural heritage as intellectual property has proven that cultural heritage protection and safeguarding serves to maintain cultural diversity, and is essential for maintaining sustainable development in a world with increasingly privatized intellectual property protections (Kono, 2009, p. 5). Moreover, intellectual property law protections are fundamental to prevent the commercial exploitation of cultural heritage.

Notably, while the consolidation of cultural expressions and difference within the ownership and authorship imposed by intellectual property law can create flourishing communities in response to the privately protected works, these public spheres remain highly vulnerable to the legal threat from the rights holder, which can serve to delegitimize and suppress creative appropriations of the copyright protected work and benefit the commodification of capitalist interests as acts of authorship (Coombe, 1998, p. 285).

Within a Japanese context, yōkai are essential to Japanese national identity and culture, as they personify a core definition of heritage (Kono, 2009, p. 16), and are a reflection of communal social customs, beliefs, and rituals (Lang, 1884; Malinowsky, 1954, p. 99). Allowing the communal usage and enjoyment of yōkai characters under Japanese copyright law is essential in order to fulfill the central policy objective of Japan's Copyright Act which is to protect the cultural property of Japan (Scott, 2006, p. 283; Foster, 2013, p. 316), "having regard to a just and fair exploitation of these cultural properties, and thereby to contribute to the development of culture". ${ }^{3}$

\section{History}

In order to understand how inequality may result from a system of intellectual property applying to cultural heritage, it is important to recognize the ways in which the cultural form was practiced prior to intellectual property's introduction, and how intellectual property law has impacted its development (Fish, 2016, p. 139). As noted by legal anthropologist Rosemary Coombe, intellectual property law regulating culture has also raised a range of legal and ethical dilemmas arising from its justifications from a colonial Western philosophical tradition of natural rights, Lockean theories of property, and categories borrowed from Enlightenment traditions, to rationalize structures that regulate intellectual creations and can reflect and enforce subjection and subjugation (Coombe, 1998, pp. 7-8).

\footnotetext{
${ }^{1}$ Ibid art 2s 20; Tokyo Chiho Saibansho [Tokyo Dist. Ct.] Nov. 20, 1972, Sho 46 (wa) No. 273, 289 Hanrei Taimuzu [Hanta] 77 (Japan); Saiko Saibansho [Sup. Ct.] Mar. 28, 1980, Sho 54 (o) No. 923, 415 Hanrei Taimuzu [Hanta] 100 (Japan).

2 Chosakukeho (Copyright Law of Japan) 1970 (Japan).

3 Chosakukeho (Copyright Law of Japan) 1970 (Japan), Art. 1.
} 


\section{Who Can Claim Ownership Over Japanese Folklore?}

Hegemonic Western contemporary copyright protection systems assign "ownership" in accordance with Enlightenment era understandings of authorship and knowledge, where property is assigned to individual actors (Fish, 2006, pp. 189, 193). The philosophical justification of this view is that an author's work is seen as a direct consequence of the author's labour and as a result the author is seen to be morally deserving of having their work protected (Fish, 2006, pp. 189, 193). This framework struggles to define ownership when work is produced collaboratively and is outside a rational-scientific or textual format (Fish, 2006, pp. 189, 193). A flaw in the doctrinal constructions of intellectual property having sole authorship is that information, and in particular folkloric knowledge, often has numerous contributing sources (Fish, 2006, pp. 189, 193). This diversity in contributing sources is prevalent when evaluating Japanese cultural knowledge, particularly with regard to the historical origins of $y \bar{o} k a i$.

Professor Deborah Shamoon (2013) argued that the modern media's of engagement with yokkai characters embodies a wide degree of flexibility and distinct interpretation, and invited a degree of playful interaction and parody based on the rich cultural traditions of Japanese folklore. As a result, her argument suggests that each use of $y \bar{o} k a i$ is its own unique and innovative invention, and is thus not simply a transplanted copy of another author's work. This is significant for the purposes of ownership under intellectual property law, as her argument suggests that the usage of $y \bar{o} k a i$ characters can involve a degree of inspiration without being a copy that infringes another author's copyright protected interest.

The historical origins of yōkai embody Deborah Shamoon's argument for an interplay between interpretation and reproduction. Edo period yōkai cataloguer and artist Toriyama Sekien, whose extensive yōkai databases are largely responsible for the modern Japanese understanding and interpretation of yōkai (Shamoon, 2013, p. 277), drew from earlier folklore traditions in both Japan and China (Foster, 2009, p. 55), with inventions which he freely mixed amongst yōkai he personally imagined (Foster, 2009, pp. 74-75). Another popular user of $y \bar{o} k a i$ was Mizuki Shigeru, and through his works he creatively interpreted, preserved, and articled yōkai (Shamoon, 2013, p. 280). Mizuki himself was a firm believer in yōkai and drew from his own claimed yōkai experiences, where he claimed his knowledge was catalogued from verbal story telling from an elderly woman within his rural village of Sakaiminato (Shamoon, 2013, p. 280). He claimed that this orally communicated knowledge was a major influence upon his conception of yōkai, and is claimed to be mostly passed down through his local rural experiences (Shamoon, 2013, p. 281). Mizuku's conceptions of yōkai have now been privately copyright protected and been purchased by Shouchiku Film Production Company, leading to these characters being left out of cinema productions by rival production companies out of fear of copyright infringement (Papp, 2010, pp. 138, 150).

These yōkai depictions from Toriyama Sekien and Mizuki Shigeru arise from a dual approach of original invention and parody, and folklore Professor Michael Foster (2015) argued that the historical basis of yōkai forms from expositions of the surrounding world consisting of a "symbiotic process of interpretation and creation" (p. 244). Yōkai can therefore be seen as the byproduct of both a reproduction of previous concepts mixed alongside innovative new ideas, with visual depictions inspired by the era they were produced in (Papp, 2010 b, pp. 11, 19). This combination presents a challenge to intellectual property law which struggles to determine who has ownership over folkloric yōkai characters and to what extent these yōkai characters in a work 
can be privately protected. The complexity is heightened by yōkai each attracting their own mythology, which is visualized and fixed into given form by artists and cataloguers.

Moreover, the philosophical framework of yōkai forms a highly important aspect of Shinto mythology, and Shinto shrines celebrate distinct yōkai, with picture scrolls of local deities and yōkai are commissioned by modern designers (Papp, 2010b, p. 11) that become associated with religious practice within the local shrine (Papp, 2010b, p. 11). This presents a further challenge when regulating who can privately obtain the moral rights to $y \bar{o} k a i$, as they retain an important public religious and political function.

Through the historical development of $y \bar{o} k a i$, it can be seen that they embody a large variety of cultural themes, and come from a vast diversity of sources both from within Japan and throughout Asia. Therefore, it becomes impossible to ascertain a universal and defined "author" of yōkai.

As a result, intellectual property law regulating Japanese yōkai must, as anthropologist Michael Brown (2003) argued, not be asking "Who owns native culture?" but "How can we promote respectful treatment of native cultures and indigenous forms of self-expression within mass societies" (p. 10).

\section{How Can Intellectual Property Law Facilitate the Promotion of Respectful Treatment of Yōkai Culture Within Japan?}

Ensuring that $y \bar{o} k a i$ and folkloric knowledge is treated respectfully, and therefore is not privatized and copyrighted at an extent to which they are unable to be enjoyed by the broader public is of vital significance as they are form an essential aspect of Japanese cultural identity (Kono, 2009, p. 19). Extensive privatized ownership over heritage creates a moral dilemma where an individual becomes capable of claiming exclusive rights over culture that is a vital aspect of Japanese communal cultural practice and thus ought to belong to the broader Japanese community (Brown, 2003, p. 197). To many communities, including within Japan, folklore plays a vital role as it constitutes a fundamental basis of social identity (Lewinski, 2008, p. 343), and comprises part of "the rich and varied but non-regenerative resources as well as the incomparably valuable heritage of human society" (Adewopo, 2013). Recognition of cultural property through law is of vital significance to cultural heritage; this is particularly evidenced by Mabo in an Australian context, which displayed the ways in which the assignment of property through law is of vital moral significance as property mediates the world in which people interact and the relationships between communities and governmental institutions (Anderson, 2009, p. 36). ${ }^{4}$

The Japanese Copyright Act as it stands does not sufficiently consider internal cultural factors, and thus does not promote the respect treatment of yokai culture within Japan as a mass society. When drafting its current copyright legislation, the Japanese government sent a government official to Europe and the United States to study concepts of copyright (Foster, 2013, p. 332). This resulted in the official ultimately basing Japanese copyright law on Continental European concepts, which maintains its colonial roots through its droit d'auteur (author's rights) philosophy, which is formulated upon an author's natural right to their own creations, and is reflected in the instrument's division of creation rights into either moral or economic rights (Ganea \& Heath, 2005, pp. 69-70; Foster, 2013, p. 332). ${ }^{5}$ Although Japan has protections afforded to what is deemed as "Intangible Cultural Property" unrelated to folklore under the Japanese government's law for the protection of

\footnotetext{
${ }^{4}$ Mabo v Queensland [No. 2] (1992) 175 CLR 1.

5 Chosakukeho (Copyright Law of Japan) 1970 (Japan).
} 
cultural properties (Administration of Cultural Affairs in Japan, 2007), the term in its usage refers exclusively to a Lockean conception of human skills possessed by specific individuals and groups, and thus does not apply to intangible cultural knowledge, such as yōkai. Moreover, despite recognizing the cultural significance of folk cultural property as being, "indispensable for understanding transition in the daily lives of Japanese people", (Administration of Cultural Affairs in Japan, 2007), there remains no mechanisms to register or protect interests in folk cultural property when it is intangible.

As a result, the current systems in place for protecting cultural interests through intellectual property law within a Japanese context do not protect cultural interests in intangible folkloric knowledge and yōkai. As such intellectual property law in Japan fails to facilitate the respectful treatment of $y \bar{o} k a i$ and folkloric culture within Japan as a mass society and should be critically reevaluated.

\section{Issue One: The Significant Extent to Which Intellectual Property Law Is Harmful in Its Regulation of Yōkai}

\section{Yōkai as a Cultural Commercial Resource}

Culture is a modern-day commodity, and markets searching for novelty and authenticity often turn folklore into exploitable cultural resources (Brown, 2003, p. 4). These cultural resources are reified and animated as an asset which is capable of being leveraged by communities and governments for tangible economic benefits through the commercial marketing of distinct goods, places, and experiences (Coombe, 2016, pp. 247, 250). Yōkai are no exception to this principle and are commonly commercially privatized and trademarked by individual rights holders.

The notion of $y \bar{o} k a i$ as a cultural commercial resource is an issue as there is considerable overlap between privatized depictions and communal cultural icons of yōkai. As a result, trademarked and copyrighted depictions of yōkai have an overwhelming influence on how yōkai are perceived, depicted, reproduced, and consumed by the broader public. For example, local groups and towns often informally commodify yōkai as local symbols without regard as to whether they are infringing upon a copyrighted character, idea, or design (Foster, 2009, p. 207). Conversely, private corporations often commercialize and privately trademark an exclusive interest in yōkai previously considered to be in public domain (Foster, 2009, p. 207). These include trademarked company logos and corporate mascots (yuru-kyaa), which turn yōkai into distinct brands to represent a product, such as Tokyo-Mitsubishi Bank's prominent and well-received credit card with features two publicly beloved yōkai a kappa and a tanuki (Foster, 2009, p. 207). More recently, the popular Yōkai watch has netted 55.2 billion yen during its first year of Japanese sales in 2014 (Nitta, 2015), and has accumulated over \$1 billion USD in merchandising revenue alone at the point of its United States release in 2016 (Webster, 2016). Moreover, popular film production studio, Studio Ghibli has further utilized and copyright protected their interest in yōkai to great commercial success with two of their most successful films, Spirited Away and Princess Mononoke being centered on yōkai and grossing for a combined box office total of \$448,475,308 USD (Baseel, 2016; Pineda, 2017). Despite some perceptions that yōkai do not belong to anybody (Foster, 2015, p. 8), businesses currently hold major economic interests in yōkai and have trademarked, copyright protected, and marketed these $y \bar{o} k a i$ as their own property. 
The substantial economic benefit of $y \bar{o} k a i$ as cultural heritage within the commodity market is clear, however, similar to issues with Aboriginal Australian art and intellectual property, economic value had been generated before other matters governing the legitimacy of subject matter such as originality and authorship for the intellectual property rights to yōkai had been ascertained (Anderson, 2009, p. 101). Moreover, intangibility, and sense of spirituality comprise core features of their value as a cultural commodity (Foster, 2015, p. 105; Nakata, 2002, pp. 281, 282), and the private protection of these yōkai by production studios cheapens this value.

\section{Current Strict Japanese Copyright Law Strict Interpretation Regarding Characters and Concepts}

These privatized trademarked yōkai further become an issue in light of Japan's extensive dōjinshi (self-published derivative works) market that often violates copyright, and is estimated to be worth between $\$ 225$ million and \$270 million USD (Blagadon, 2012). Many of these fan-made publications and narratives unlawfully reproduce yōkai characters from works that are formally protected by intellectual property law (Foster, 2013, p. 315; Mehra, 2002, pp. 155, 164), and these violations are further confounded by the fact that Japan does not have a generally applicable provision for "fair use" as is present in other jurisdictions (Kojima, 2010, pp. 358, 359; Nakazaki, 2010, p. 1). As a result, a strict interpretation of copyright limitations in Japan results in a vast array of activities ordinarily protected under fair use to become copyright infringement (Kojima, 2010, p. 359), and these authors have found themselves sued by publishers (Lessig, 2005, p. 27). The case of Tokimeki memorial jiken, heard at the Tokyo District Court, demonstrates that a strict interpretation of copyright infringement and lack of fair use protections can be readily applied to characters and personalities and even narrative concepts, and are therefore readily applicable to yōkai (Kojima, 2010, pp. 370-376). ${ }^{6}$ Moreover, this immense potential for copyright infringement for character concepts was held to strictly apply Section 27 of the Japanese Copyright Act which grants the private rights owner "exclusive rights to translate, arrange musically or transform, or dramatize, cinematize, or otherwise adapt his work". ${ }^{7}$ This is particularly concerning when granting exclusive rights to an owner for $y \overline{o k a i}$ characters given their frequent usage in much of popular media and translated works. The extremely strict moral rights assigned to folklore characters under this section support Rosemary Coombe's theory that the intellectual property ideologies of authorship and the commodification of culture, based on the legitimizing rhetoric of modernity, serve solely to protect corporate hegemonies over monological domains of mass culture (Coombe, 1998, p. 283). Through this, the rights of private investors are legitimized to effectively control the circulation of corporately produced texts and their reworkings by alterity, further limiting the capacity for suppressed groups to engage in cultural activities that negotiate with hegemonic media forms to better reflect their own cultural situation (Coombe, 1998, p. 283). A result of this is cultural goods and services previously held by a local community, become conceived and distributed by multinational corporations who then overpower local communities in the creation and maintenance of their own cultural identity (Appadurai, 1991, p. 198). This is of particular socio-legal significance with regard to yōkai and folklore more broadly, as texts, characters, and narratives previously considered a vital aspect of a local community's connection with the past or their own identity can be privately purchased and copyright protected by an exclusive rights holder, thus limiting their capacity to engage with their own local history.

${ }_{7}^{6}$ Tokimeki memorial jiken, Tokyo District Court, August 30, 1999, Hanji 1696 (Japan) 14.

7 Chosakukeho (Copyright Law of Japan) 1970 (Japan), Art. 27; Tokimeki memorial jiken, Tokyo District Court, August 30, 1999 , Hanji 1696 (Japan) 14. 


\section{The Commercial Issues With Western Copyright Law's Application to Yōkai}

Copyright law from an idealistic historical perspective serves to appreciate and reward individual genius (Coombe, 1998, p. 219). Through this, the intent of copyright law is to protect works which are understood to embody the distinct personality of their author, and through this understanding the expressive component of an original is venerated to the extent that reproduction or imitation is deemed theft (Coombe, 1998, p. 219). This perspective is philosophically justified through the Lockean theory which views the origin of property in labour, in which expressive creation is seen as authorial work, and where an original product arises from mental labour, which allows an author to claim both the physical production and the literary or artistic endeavor itself (Coombe, 1998, p. 219; Young, 2008, p. 27). However, this concept that each person has a property of their person, and that the labour of this person produces new things which becomes the person's valuable property (Coombe, 1998, p. 37), struggles to apply to yokkai both culturally and commercially.

The commercial dependence of yokai on public usage and enjoyment can be seen through the way in which their popularity and commercial success is tied to the perception of $y \bar{o} k a i$ being shared cultural heritage and thus available for everyone's enjoyment and appropriation (Kono, 2009, p. 18; Foster, 2015, p. 8). This perception in Japan of $y \bar{o} k a i$ as public culture is core to the success of $y \bar{o} k a i$ in popular culture narratives, and contrasts with other perceived methods of cultural ownership of folklore in South-East Asia, such as the Indonesian government's 2002 Copyright Law which vests ownership of folklore as state intellectual property (Aragon, 2014, pp. 15-17).

However, the public perception of $y \overline{o k a i}$ truly being in the public domain is erroneous, ${ }^{8}$ and the ways in which corporate branding in Japan has vested interests in specific yōkai characters and the protection of these characters from intellectual property theft contradicts the rationale for their public popularity (Foster, 2009, p. 207). This results in the core reasoning for the popularity of yōkai being under threat from extensive and overbearing intellectual property law protections.

\section{Issue Two: The Pitfalls of UNESCO's Convention for the Safeguarding of the Intangible Cultural Heritage When Applied to yōkai}

\section{Purpose of the Convention for the Safeguarding of Intangible Cultural Heritage}

The historical cataloguing of folklore is not unique to a Japanese context, and has been carried out globally, for example in a European context through the collections of the Brother's Grim, Perault, and Basile in collecting and recording fairytales, which can be seen as an earlier example of safeguarding cultural heritage (Uytsel \& Kono, 2009, pp. 43, 113-114). Global attempts to recognize and catalogue folklore have recently been enacted through UNESCO's Convention for the Safeguarding of the Intangible Cultural Heritage, ${ }^{9}$ which encourages formal inventory making of intangible cultural heritage (Uytsel \& Kono, 2009, p. 46). Article 2 of the Intangible Cultural Heritage convention defines intangible cultural heritage as "practices, representations, expressions, knowledge, skills, instruments, objects, artefacts and cultural spaces that are delineated by community

\footnotetext{
${ }^{8}$ Chosakukeho (Copyright Law of Japan) 1970 (Japan), Art. 27.

9 Convention for the Safeguarding of the Intangible Cultural Heritage, signed 17 October 2003, 2368 UNTS 3 (entered into force 20 April 2006).
} 
identification" (Uytsel, 2009, pp. 113, 117). ${ }^{10}$ Although this would seem to appropriately encapsulate yōkai, global issues have arisen regarding the effectiveness of the cataloguing systems contained within this instrument and its effectiveness of encapsulating the diversity and fluctuating nature of folklore, and these issues are further prevalent in its potential applicability to Japanese yōkai. This paper will consider the effectiveness of formally cataloguing intangible cultural heritage and potential issues arising from this process.

The emergence of much of modern intellectual property law, and the colonial foundation that constitutes it, does not fully understand the properties of native culture and the consequences of possessing identity (Coombe, 1998, pp. 246-247). The Convention for the Safeguarding of Intangible Cultural Heritage attempts to combat this gap in intellectual property law with its aim of safeguarding the intangible cultural heritage of communities, groups, and individuals for the purposes of recognizing cultural diversity and supporting long-term sustainable development (Kono, 2009, p. 5; Akagawa, 2015, p. 11). Many yōkai have been informally catalogued and interpreted by a variety of individual private authors, while it may seem simple to protect these individual and personal depictions of $y \bar{o} k a i$ under the convention as inventories of intangible cultural heritage using the UESCO convention (Uytsel, 2009, p. 114); the UNESCO convention has so far struggled to fairly quantify collective knowledge, ideas, and traditional cultural expressions (Kono, 2009, p. 17).

\section{Issues With the UNESCO Convention and Its Requirements to Define Community Ownership in Order to Protect Intangible Cultural Heritage}

Despite their good intentions, the systems suggested by the UNESCO convention present a fundamental difficulty as it relies on clearly defining a community as the owner of the expression. This approach of defining a specific community owner is inconsistent with the essence of yōkai folklore culture, which ultimately springs from collective intangible knowledge (Shamoon, 2013, p. 277). Moreover, unlike the fixed registration system imposed by the UNESCO convention, this cultural knowledge is not fixed, and with each derivation and re-interpretation of yōkai folklore this intangible knowledge continues to evolve (Shamoon, 2013, p. 277). Like much of intangible cultural heritage, yōkai folklore is a living heritage and therefore is subject to continual change and re-interpretation (Brown, 2005, pp. 40, 45). These factors present key issues for the UNESCO protection instruments due to the need for the convention to define ownership, register interests, and protect them in a way that is often time-limited (Kono, 2009, p. 15).

There are many potential benefits and downsides in attempting to define ownership of yōkai under the UNESCO convention, and the interplay between public domain and private protection forms tension as both historically and in modern depictions yōkai are formed from a process of interpretation and reproduction. Yōkai in the public domain cannot truly exist entirely independently from privately protected depictions as the fundamental process of reproduction and interpretation will often absorb these private depictions into the $y \bar{o} k a i$ "canon" (Shamoon, 2013, pp. 277-280); this causes an issue with the UNESCO convention's desire to ascertain a specific community rights holder that can claim personal ownership over the cultural past, and thereby exclude other interest holders who may have their own competing interest in that past.

Moreover, another issue is that despite the potential benefits from protecting community interests in $y \bar{o} k a i$ ${ }^{10}$ Convention for the Safeguarding of the Intangible Cultural Heritage, signed 17 October 2003, 2368 UNTS 3 (entered into force
20 April 2006), Art. 2 . 
by registering them as communal intellectual property through UNESCO is that some communities would prefer these rights to remain in the public domain rather than be formally registered. For example, Michael Brown notes that many communities prefer the benefits of security through obscurity over formal protection mechanisms, and thus would much rather their interest not be formally defined and catalogue (Brown, 2005, p. 56).

Additionally, cataloguing cultural heritage in the convention's current system requires a defined community (Branislav \& Kono, 2009, pp. 145, 146). The necessity of identifying members of the community with specified ownership to yōkai is of cultural concern due to the potential socio-cultural issues clearly defined community ownership in Japan which can generate, such as the perpetuation of Nihonjinron. Nihonjinron, is a concept which sociology professor Kosaku Yoshino critiques as attempting to explain the uniqueness of Japan through a misplaced presumption of "uniquely Japanese modes of thinking" (Yoshino, 1992, pp. 9, 37). Nihonjinron views are founded on the misrepresentation of Japan as culturally and socially homogenous, and unchanging from pre-history (Dale, 2012, p. i). Nihonjinron erroneously asserts that Japanese people have universally homogenous racial and psychological traits that differ significantly from all other societies (Dale, 2012, p. i). These views are perpetuated regarding Japanese culture and society internationally in the presentation of Japan as an oriental "other" (Said, 1979, pp. 9, 32, 34; Dale, 2012, p. i), as well as domestically in forging a culturally nationalistic communal identity that excludes ethnic and cultural minority groups. This concept of Nihonjinron falls under a global colonial stereotypical trend, which relays ideas of modern national founding's, often stressing racial or cultural purity and unity alongside colonial stereotypes (Coombe, 1998, p. 191). Intellectual property law in attempting to define community stake holders in Japan through the UNESCO convention's requirement for a pre-determined community stakeholder carries the significant burden of perpetuating the view of Japan as culturally, socially, and racially homogenous and this would be exclusory to minorities. Any attempt by intellectual property law to define community stakeholders to yōkai should be aware of this potential issue. Moreover, it denies other potential community stakeholders in yōkai, such as China, from which many of the folkloric yōkai myths stemmed.

The influence of Nihonjinron and Orientalism on viewing pre-existing cultural forms in Japan is of particular significance to intellectual property law in Japan, and to a lesser extent the UNESCO system of specified community ownership, contains categories of authorship and paternity that serve to orientalize cultures outside of the Western self, and obscure their historical agency, transformations, and internal differences (Coombe, 1998, p. 226). As such, the attempt to assign Western enlightenment era philosophical conceptions of ownership and possession to $y \bar{o} k a i$ as cultural identity denies the cultural diversity and intercultural contact that forged the existence of yōkai. Furthermore, the time-locked nature of registered interests under the UNESCO convention instead misrepresents Japan as a timeless and unified cultural whole, with clearly defined ownership of specific yōkai characters.

\section{Issue Three: Difficulties Regarding the Strong Moral Rights and Highly Limited Fair Use Protections in Japanese Copyright Law}

The current highly conservative and limited fair-use defenses in Japanese intellectual property law have a highly negative impact on the cultural tradition and usage of yōkai. The Copyright Act in Japan has very strong moral rights and Section 1 of Art. 20(1) states that the author has the right to maintain the integrity of their work 
and title, and no distortion, mutilation, or other modification thereof shall be made against their intent. ${ }^{11}$ Therefore even when the user's modification is beneficial to an author, if an author disagrees with its use, it is prima facie infringement (Sudo \& Newman, 2014, p. 40; Fujiwara et al., 2008, pp. 393, 393-394). Moreover, these moral rights to reputation subsist long after death of the author, for example, the case of Isamu Noguchi Foundation Inc $v$ Keio University where it was considered that the moving of a sculpture might harm the intended artistic value of a late author (Sudo \& Newman, 2014, p. 40). ${ }^{12}$ These views of culture as fixed memory are problematic in the context of $y \bar{o} k a i$ due to their tradition of appropriation and mixture. These strict regulatory regimes and lack of fair use protections when applied to yōkai contradict primary policy objective of Japanese intellectual property cultural policy which is, "in the belief, from Japanese experience, that it is important for each country to preserve its individual culture in the course of development" (Cox \& Bruman, 2011, p. 1; Kawada \& Hayashi-Denis, 2004, pp. 32, 33-34).

These strict moral rights have very limited defenses for fair-use, and common defenses, such as the use of copyright protected material for educational purposes and parody are not currently recognizable as the permitted usage of work protected by copyright (Kojima, 2010, p. 359; Nakazaki, 2010, p. 1). ${ }^{13}$ This is highly problematic for the cultural enjoyment of $y \bar{o} k a i$ as their usage and historical development emerged from significant degree of intertextuality and parody between works (Shamoon, 2013, pp. 276-277). The heavy and vast limitations on intertextuality and parody within Japanese intellectual property law is of vast socio-legal significance, as parody and appropriation allow local communities to deploy texts, symbols, and images in ways that reflect their own socio-cultural conditions and serve as an avenue of empowerment (Coombe, 1998, p. 271).

Fair use protections for the public enjoyment of folklore are critical for ensuring the recognition of cultural values and encouragement of tolerance (Forrest, 2010, p. 363). Moreover, folklore as an element of cultural heritage is in many ways at odds with the modern operation of intellectual property law, for example, cultural heritage has universal beneficiaries and is eternal and everlasting, whereas intellectual property rights are granted to targeted groups or individuals and are territorial in character and of a limited duration (Shyllon, 2015, p. 59). Intellectual property law in regulating cultural forms, such as yōkai, transforms figures from cultural history into private properties that constrain the wider public from cultural and political practice (Coombe, 1998, p. 69). This is significant as the protections granted to trademarked characters, particularly when an aspect of communal cultural heritage, have the capacity to escalate into a broader power to prohibit all forms of reproductions of the work, and grow into a vehicle of suppression that curtails social commentary (Shyllon, 2015, p. 72; Denicola, 1982, pp. 158, 190). A democratization of access to the practice of yōkai in light of trademarked characters is essential to the furthering of expressive activity for all people, rather than solely granting powerful actors even more capacity to dominate cultural arenas (Coombe, 1998, p. 77). In this sense a fair use defence for cultural forms such as $y \overline{o k a i}$, or equivalent means of protection, is essential in order to counter the means through which, "Laws of intellectual property privilege monologic forms against dialogic practice and create significant power differentials between social actors engaged in hegemonic struggle" (Coombe, 1998, p. 86).

\footnotetext{
11 Chosakukeho (Copyright Law of Japan) 1970 (Japan), Art. 20 s1.

12 Isamu Noguchi Foundation Inc v Keio University, Tokyo District Court, June 11, 2003, H15 (yo) No. 22031, 1840 Hanrei Jiho 106 (Japan).

${ }^{13}$ Chosakukeho (Copyright Law of Japan) 1970 (Japan).
} 


\section{Potential Solutions}

A potential solution to address the necessity for the introduction of a fair use protection system for cultural forms, such as $y \bar{o} k a i$ that is capable of pragmatically addressing the unclear space between public and private that yōkai embody, as well as protect the enjoyment of yōkai as an aspect of essential cultural heritage, is the expansion of fair use doctrine based on the United States codified Fair Use Defence. An expansion of the Japanese fair use doctrine would be of significant benefit to protecting yōkai under intellectual property law, and would serve to both protect the uniqueness of copyrighted works, and ensure the continued public enjoyment of yōkai as shared culture.

The open-ended general limitation clause from the American system of fair use is rendered under Section 107 of the United States Copyright Act (Sudo \& Newman, 2014, p. 40). ${ }^{14}$ These factors being a potential defence for the usage of cultural forms, such as the usage of yokai would be highly effective for the public enjoyment of $y \bar{o} k a i$ as folklore knowledge, due to the transformative nature of their usage, the historical nature of their characterisation, and the market of appropriation expected for $y \bar{o} k a i$ usage. Moreover, the limited application of this potential section to areas of cultural heritage in Japan would further support its introduction's primary purpose of protecting the cultural enjoyment of cultural forms.

However, acceptances of current international regimes such as that posed by the UNESCO convention, or extensions of fair use protections, are not the only potential pathways to facilitate a balance between private usage and public access to yōkai. Alexandra Lippman notes that in Brazil, free culture (cultura livre) was championed as an ideal model for creative appropriation by international open IP supporters (Lippman, 2014, p. 11), built on a "cannibalistic" approach that swallows pre-existing culture and produces a stronger synthesis through live show formats such as techno-brega (Lippman, 2014, p. 11). These usages of copyrighted work is successful without strict copyright restrictions as their methods for business generation are independent of an exclusive copyright to the work (Lippman, 2014, p. 12). Moreover, this enjoyment does not infringe on the original right's holders profits from their original work (Lippman, 2014, p. 12). This is in stark contrast to Japanese copyright laws regarding enjoyment of a work without infringing on the right's holders profits, as displayed in the case of JARSAC v K. K. Tsuge, et al. (Doi, 2010, pp. 631, 635) ${ }^{15}$ where a society of composers successfully brought an action against schools teaching social dancing using reproduced recorded music from JARSAC. Similar to the live show format of techno-brega the music was played live and did not primarily profit off of its digital sales. However, despite JARSAC's music being used for an educational purpose, and not being resold, JARSAC were successful in suing the schools for using their works.

The vastly divergent outcomes of these two scenarios reveal the strict conservative nature of Japanese copyright law and the necessity for it to relax in its regulation of cultural forms. The Brazilian progressive alternative copyright practices effectively serve as a resistance to hegemonic corporate power, enable broader participation in culture, and raise questions regarding the obfuscator rhetoric surrounding open access (Lippman, 2014, pp. 11-12). Whereas, Japan's conservative protections regarding copyright disempower consumers seeking to deprive a cultural, or even educational benefit from copyrighted works, even in scenarios that serve no

1417 USC $\S 107$.

15 JARSAC v K. K. Tsuge, Nagoya Chiho Saibansho [Nagoya Dist. Ct.] Feb. 7, 2003, H14 (wa) No. 2148, 1840 Hanrei Jiho [Hanji] 126 (Japan); Nagoya Koto Saibansho [Nagoya High Ct.] Mar. 4, 2004, 1870 Hanrei Jiho [Hanji] 123 (Japan). 
tangible detriment to the right's holders. Although Brazil is a vastly different social context from Japan, Japanese copyright legislators could take a degree inspiration from the cultura livre system with regards to aspects vital to Japanese cultural heritage such as $y \bar{o} k a i$ and serve to protect the public interest in cultural heritage through a limited cultura livre model. This would be particularly beneficial as the profit from yōkai does not come from the exclusive rights to the specific $y \bar{o} k a i$, but from their own interpretations of the work, and the notion of public participation in $y \bar{o} k a i$ culture. This approach is consistent with the theorization of an Asian commons argued by Liand Iyengar and Nitchani, who suggest that Asia and the commons should be seen as diverse and always transforming (Fish, 2014, pp. 7, 9). This paper ultimately suggests that in Japan an informal and abstract cultura livre approach with regard to forms of folkloric cultural heritage knowledge would be superior to the expansion of fair use protections for the purposes of allowing broader public engagement with yōkai as shared cultural heritage.

\section{Conclusion}

The regulation of cultural heritage and communal cultural identity under copyright protection laws remains a complicated and divisive matter that at times is inconsistent with the philosophical Lockean theories of property that underpin modern intellectual property law (Coombe, 1998, pp. 7-8). The role of intellectual property law as a colonizing influence, as well as the colonial justifications that underpin this influence, is of large socio-cultural significance due to the way in which intellectual property law when applied to cultural heritage can reflect the histories of imperialism, colonialism, annexation of territory, and political disenfranchisement between public and private interests all competing for "ownership" to cultural knowledge and identity (Coombe, 1998, p. 33).

This paper has taken a critical stance on the European enlightenment philosophical thought that underpins intellectual property law and empowers rights holders to privilege the speech of authors, and silence the expression and negotiated reception to authorship of alterity (Coombe, 1998, p. 273). This paper has further attempted to promote the view that the influence of intellectual property law needs to be critically re-evaluated, in regards to $y \bar{o} k a i$ as a specific cultural form, as well as its influence more broadly in regulating and controlling cultural identity, both in Japan and globally. This paper ultimately concludes that a cultra livre model for forms of cultural heritage in Japan such as yōkai would be of significant public benefit for maintaining their communal benefit through their presence as a vital aspect of Japanese cultural identity and narrative. Although this cultra livre model applying to forms of cultural heritage would be a preferred option, a potential more limited alternative that would also create a substantial benefit for the wider community would be an expansion of fair use defences with regards to the usage of cultural figures, such as yōkai.

\section{References}

Anderson, J. (2009). Law, knowledge, culture: The production of indigenous knowledge in intellectual property law. Cheltenham: Edward Elgar Publishing Ltd.

Adewopo, A. (2013, March 27). Protection and administration of folklore in Nigeria. Nigerian Law Intellectual Property Watch. Retrieved from https://nlipw.com/protection-administration-folklore-nigeria/

Administration of Cultural Affairs in Japan. (2007 June). Cultural properties for future generations.

Appadurai, A. (1991). Global ethnoscapes notes and queries for a transnational antrhopology. In R. Fox (Ed.), Recapturing anthropology: Working in the present (pp. 191-210). Santa Fe: School of America Research Press. 
Aragon, L. (2014). Law versus lore copyright and conflicting claims about culture and property in Indonesia. Anthropology Today, 30(5), 15-19.

Akagawa, N. (2015). Heritage conservation and Japan's cultural diplomacy: Heritage, national identity and national interest. Abingdon-on-Thames: Routledge.

Brown, M. (2003). Who owns native culture. Cambridge: Harvard University Press.

Brown, M. (2005). Heritage trouble: Recent work on the protection of intangible cultural property. International Journal of Cultural Property, 12(1), 40-61.

Baseel, C. (2016, November 28). Anime your name passes Princess Mononoke on all-time Japanese box office list. Sora News. Retrieved from https://soranews24.com/2016/11/28/anime-your-name-passes-princess-mononoke-on-all-time-japanese-box-office-list-is-no w-at-number-3/

Blagadon, J. (2012, August 21). Comiket: Shopping for undergrorund manga at the world's biggest comic book event. The Verge. Retrieved from https://www.theverge.com/2012/8/21/3238607/japan-comic-convention-market-comiket-summer-2012

Branislav, H., \& Kono, T. (2009). Conceptualization of a community as a holder of intangible cultural heritage. In T. Kono (Ed.), Intangible cultural heritage and intellectual property: Communities, cultural diversity and sustainable development (pp. 145-158). Cambridge: Intersentia.

Coombe, R. (1998). The cultural life of intellectual properties: Authorship, appropriation and the law. Durham, North Carolina: Duke University Press.

Coombe, R. (2016). The knowledge economy and its cultures. HAU Journal of Ethnographic Theory, 6(3), 247-275.

Cox, R., \& Bruman, C. (2011). Making Japanese heritage. Abingdon-on-Thames: Routledge.

Dale, P. (2012). The myth of Japanese uniqueness. Abingdon-on-Thames: Routledge.

Denicola, R. (1982). Trademarks as speech: Constitutional implications of the emerging rationales for the protection of trade symbols. Wisconsin Law Review, 1982(2), 158-207.

Doi, T. (2010). Availability of the "fair use" defense under the Copyright Act of Japan: Legislative and case law developments for better adapting it to the digital/network environment. Journal of the Copyright Society of the USA, 57(3), 631-653.

Fish, A. (2006). The commodification and exchange of knowledge in the case of transnational commercial yoga. Anthropology Today, 13(2), 189-206.

Fish, A. (2014). The place of "culture" in the access to knowledge movement comparing creative commons and yogic theories of knowledge transfer. Alternative Copyright, 30(5), 7-10.

Fish, A. (2016). Ethnographic explorations of intellectual property claims to yoga: A series of unexpected events. In H. Rinkler (Ed.), Unexpected anthropology: New spaces, places, and methods for applied anthropology (pp. 148-162). Abingdon-on-Thames: Routledge.

Foster, M. (2009). Pandemonium and parade: Japanese monsters and the culture of yōkai. Oakland, California: University of California Press.

Foster, M. (2013). Parody's precarious place: The need to legally recognize parody as Japan's cultural property. Seton Journal of Sports and Entertainment Law, 23(2), 313-344.

Foster, M. (2015). The book of yokai: Mysterious creatures of Japanese folklore. Oakland, California: University of California Press.

Fujiwara, H., Otsuka, I., Saito, H., \& Tsuda, Y. (2008). Chosakuken no Kansetsu Shingai no Houri to Sono Genkai (The rule of indirect infringement of copyright and its limitation). In H. Fujiwara et al. (Eds.), Chosakukenhou no Shin ronten (New issues of Japanese copyright act) (pp. 393-466). Tokyo: Commercial Law.

Forrest, C. (2010). International law and the protection of cultural heritage. Abingdon-on-Thames: Routledge.

Ganea, P., \& Heath, C. (2005). Japan copyright law: Writings in honour of Gerhard Schricker. Netherlands: Kluwer Law International.

Kono, T. (2009). Convention for the safeguarding of intangible cultural heritage. In T. Kono (Ed.), Intangible cultural heritage and intellectual property: Communities, cultural diversity and sustainable development (pp. 3-42). Cambridge: Intersentia.

Kojima, R. (2010). Contemporary problems in Japanese intellectual property law: Copyright limitations and exceptions. Indirect copyright infringement, and select issues related to private international law. Japanese Yearbook of International Law, 53, 358-376.

Kawada, T., \& Hayashi-Denis, N. (2004). Cooperation between UNESCO and Japan in the safeguarding of cultural heritage. Museum International, 56, 32-39. 
Lang, A. (1884). Household tales: Their origin, diffusion, and relation to higher myths. London: William Clewes and Sons Ltd. Lewinski, S. (2008). Indigenous heritage and intellectual property (2nd ed.). Netherlands: Kluwer Law International.

Lessig, L. (2005). Free culture: The nature and future of creativity. London: Penguin Books.

Lippman, A. (2014). Cannibalizing copyright? Vernacularizing open intellectual property in Brazil. Anthropology Today, 30(5), 11-14.

Mehra, S. (2002). Copyright and comics in Japan: Does law explain why all the cartoons my kid watches are Japanese imports? Rutgers Law Revue, 55, 155-204.

Malinowsky, B. (1954). Myth in primative psychology. In B. Malinowsky (Ed.), Magic, science, and religion and other essays (pp. 155-204). Illinois: Waveland Pr Inc.

Nitta, Y. (2015, July 15). Bandai Namco sees new "Gundam" taking off in Asia. Nikkei Asian Review.

Nakata, M. (2002). Indigenous knowledge and the cultural interface: Underlying issues at the intersection of knowledge and information systems. International Federation of Libraries Association Journal, 28, 281-291.

Nakazaki, T. (2010). Fair use under discussion. Euromoney Institutional Inventory PLC, 1, 1-1.

Papp, Z. (2010a). Yokai in cinema 1968-2008. In Z. Papp (Ed.), Anime and its roots in early Japanese monster art (pp. 138-157). Leiden: Brill.

Papp, Z. (2010b). Yokai art from prehistory to modernity. In Z. Papp (Ed.), Anime and its roots in early japanes monster art (pp. 8-46). Leiden: Brill.

Pineda, R. A. (2017, January 17). Shinkai's “your name.” Tops spirited away as highest grossing anime film worldwide. Anime News Network. Retrieved from https://www.animenewsnetwork.com/news/2017-01-17/shinkai-your-name-tops-spirited-away-as-highest-grossing-anime-fil m-worldwide/.111141

Shamoon, D. (2013). The yōkai in the database: Supernatural creatures and folklore in manga and anime. Marvels \& Tales: Journal of Fairy-Tale Studies, 27(2), 276-289.

Scott, G. (2006). A comparative view of copyright as cultural property in Japan and the United States. Temple International and Comparative Law Journal, 20(2), 284-362.

Said, E. (1979). Orientalism. NY: Vintage Books.

Sudo, M., \& Newman, S. (2014). Japanese copyright law reform: Introduction of the mysterious Anglo-American fair use doctrine or an EU style divine intervention via competition law? Intellectual Property Quarterly, 18, 40-70.

Shyllon, F. (2015). Cultural heritage and intellectual property: Convergence, divergence, and interface. In W. Logan, N. Craith, and U. Kockel (Eds.), A companion to heritage studies (pp. 55-68). NJ: John Wily \& Sons Inc.

Uytsel, S., \& Kono, T. (2009). Inventories as an essential part of the safeguarding process. In T. Kono (Ed.), Intangible cultural heritage and intellectual property: Communities, cultural diversity and sustainable development (pp. 43-50). Cambridge: Intersentia.

Uytsel, S. (2009). Inventory making and fairy tales: Safeguarding of intangible cultural heritage in a historical perspective. In T. Kono (Ed.), Intangible cultural heritage and intellectual property: Communities, cultural diversity and sustainable development (pp. 113-141). Cambridge: Intersentia.

Webster, A. (2016, June 24). Yo-kai watch is making another push to take over America. The Verge.

Young, E. (2008). Conjectures on original compostion. In B. Kaplan (Ed.), An unhurried view of copyright: Proposals and prospects (pp. 831-854). NJ: The Lawbook Exchange Ltd.

Yoshino, K. (1992). The Nihonjinron: Thinking elites' ideas of Japanese uniqueness. In K. Yoshino, Cultural nationalism in contemporary: A sociological enquiry (pp. 9-38). Abingdon-on-Thames: Routledge. 